\title{
PENGAMBILALIHAN HAK ATAS JAMINAN (EKSEKUSI) JAMINAN FIDUSIA DAN RAHN TASJILY PERSEPEKTIF HUKUM POSITIF DAN HUKUM ISLAM
}

\author{
Heri Kuswanto \\ Mahasiswa Prodi S1 Ilmu Hukum \\ Fakultas Hukum Universitas Muhammadiyah Mataram \\ Email:kuswantoherry4@gmail.com \\ DOI: https://doi.org/10.31764/mk:\%20jih.v10i2.2015
}

Received: Juni 20, 2019, Accepted: Agst 22, 2019 / Published: Okt 31, 2019

\begin{abstract}
The phenomenon that occurs is related to the taking over of the right to guarantee (execution) of fiduciary security and Rahn Tasjily in the execution of executions carried out by financial institutions that do not comply with applicable laws and regulations. This research uses Normative legal methods, with qualitative descriptive analysis and critical legal studies. The results of the study that the process of taking over the right to guarantee (execution) fiduciary regulated in article 29 (1) of the fiduciary guarantee law. Among the first, execution based on Grosse fiduciary guarantee certificate or executable title (fiat execution) contained in the Fiduciary Guarantee Certificate carried out by the fiduciary recipient. Second, an execution based on the execution of separate executions through public auctions by fiduciary recipients. Third, execution by sale under the hand by the creditor fiduciary himself, and fourth, fiduciary execution by claiming. Based on Islamic law, the process of expropriation of the right to guarantee (execution) Rahn Tasjily, that the procedure for executing Marhun (collateral object), if due. Murtahin must warn Rahin to pay off her debt immediately. If the Rahin still cannot repay its debt, then Marhun is forcibly sold/executed through an auction, according to sharia. Marhun sales proceeds used to pay off debt, maintenance, and storage costs that have not paid and sales costs. The excess proceeds from the sale belong to Rahin, and the shortcomings become Rahin obligations. The execution process carried out by sharia companies must be based on fatwa no. 25/DSNMUI/III/2002, and fatwa no. 92/ DSN-MUI/IV/2014. Positive law and Islamic law, which become normative references, have not been well understood and applied by the finance parties, causing injustice and legal uncertainty.
\end{abstract}

Keywords: expropriation of rights, fiduciary guarantee, rahn tasjily

ABSTRAK
Fenomena yang terjadi terkait pengambilalihan hak atas jaminan
(eksekusi) jaminan fidusia dan rahn tasjily pada pelaksanaan eksekusi
yang dilakukan oleh lembaga pembiayaan tidak mematuhi aturan
perundang-undangan yang berlaku. Penelitian ini menggunakan metode
hukum Normatif, dengan analisis deskriptif kualitatif dan studi hukum 
kritis. Hasil penelitian bahwa, proses pengambilalihan hak atas jaminan (eksekusi) fidusia telah diatur dalam pasal 29 (1) undang-undang jaminan fidusia. Diantaranya pertama, eksekusi berdasarkan grosse sertifikat jaminan fidusia atau titel eksekutorial (secara fiat eksekusi) yang terdapat dalam Sertifikat Jaminan Fidusia yang dilakukan oleh penerima fidusia. Kedua, eksekusi berdasarkan pelaksanaan parate eksekusi melalui pelelangan umum oleh penerima fidusia. Ketiga, eksekusi secara penjualan di bawah tangan oleh kreditor pemberi fidusia sendiri, dan keempat, eksekusi fidusia secara mendaku. Berdasarkan hukum Islam, proses pengambilalihan hak atas jaminan (eksekusi) rahn tasjily, bahwa prosedur pengeksekusisan marhun (objek jaminan), apabila jatuh tempo. Murtahin harus memperingatkan Rahin untuk segera melunasi hutangnya. Apabila rahin tetap tidak dapat melunasi hutangnya, maka marhun dijual paksa/dieksekusi melalui lelang sesuai syariah. Hasil penjualan marhun digunakan untuk melunasi utang, biaya pemeliharaan dan penyimpanan yang belum dibayar serta biaya penjualan. Kelebihan hasil penjualan menjadi milik rahin dan kekurangannya menjadi kewajiban rahin. Adapun proses eksekusi yang dilakukan oleh perusahaan syariah harus berdasarkan fatwa Nomor: 25/DSN-MUI/III/2002, dan fatwa Nomor: 92/DSN-MUI/IV/2014. Hukum positif dan hukum Islam yang menjadi rujukan normatif, belum difahami dan diterapkan dengan baik oleh pihak pembiayaan, sehingga menimbulkan ketidakadilan dan ketidakpastian hukum.

Kata Kunci : jaminan eksekusi fidusia, pengambilalihan hak, rahn tasjily

\section{PENDAHULUAN}

Hukum Positif atau dengan istilah ius constitutum yaitu hukum yang berlaku di suatu negara atau masyarakat tertentu pada saat tertentu. Demikian dalam kehidupan masyarakat Indonesia hukum positif adalah hukum yang berlaku di Indonesia pada waktu ini. Jadi hukum yang dipelajari disini adalah hukum yang bertalian dengan kehidupan manusia dalam masyarakat, bukan hukum dalam arti ilmu pasti dan ilmu alam yang obyeknya benda mati.

Di dalam hukum positif dan hukum agama sama-sama mengatur tentang hukum kebendaan termasuk didalamnya adalah hukum jaminan dan jaminan fidusia khususnya. Hanya saja, diantara keduanya dibedakan 
secara terminologi (istilah). Hukum jaminan di dalam hukum positif adalah "mengatur tentang jaminan piutang seseorang" ${ }^{1}$ Jaminan fidusia adalah pengalihan hak kepemilikan suatu benda atas dasar kepercayaan dengan ketentuan bahwa benda yang hak kepemilikanya dialihkan tersebut tetap dalam penguasaan pemilik benda. ${ }^{2}$ Fidusia menurut asal katanya berasal dari bahasa Romawi fides yang berarti kepercayaan. Fidusia merupakan istilah yang sudah lama dikenal dalam Bahasa Indonesia begitupulah bahasa ini digunakan dalam Undang-Undang Nomor 42 Tahun 1999 tentang Jaminan Fidusia, untuk selanjunya disebut (UUJF).

Pada hukum positif permasalahan di atas dimasukkan dalam pembahasan mengenai fidusia, maka dalam hukum Islam jaminan fidusia dikategorikan dalam rahn tasjily. Esensi rahn tasjily sendiri identik dengan jaminan fidusia, karena definisi dari rahn tasjily adalah jaminan dalam bentuk barang atas utang tetapi barang jaminan tersebut (marhun) tetap berada dalam penguasaan pemanfaatan atau pemberi jaminan (rahin) dan bukti kepemilikannya diserahkan kepada penerima jaminan (murtahin). ${ }^{3}$

Fatwa DSN-MUI (Dewan Syariah Nasional - Majelis Ulama Indonesia) No.68/DSN-MUI/III/2008 telah mengatur mengenai rahn tasjily berikut ketentuan penyitaan yang berbunyi "penyimpangan barang jaminan dalam bentuk bukti yang sah kepemilikan atau sertifikat tersebut tidak memindahkan kepemilikan barang kepada murtahin. Apabila terjadi wanprestasi atau tidak dapat melunasi hutangnya, marhun dapat dijual paksa atau dieksekusi langsung baik melalui lelang atau dijual kepihak lain sesuai prinsip syariah".

\footnotetext{
1 J. Satrio, Hukum Jaminan Hak Jaminan Kebendaan, Bandung : PT Citra Aditya Bhakti 2007. Hlm.2-3.

2 Pasal 1 ayat (1) Undang-Undang No 42 Tahun 1999.

3Fatwa DSN-MUI No.68/DSN-MUI/III/2008 Tentang Rahn Tasjily.
} 


\section{METODOLOGI}

Jenis penelitian yang digunakan yaitu penelitian hukum normatif. Penelitian hukum normatif adalah dengan meneliti buku-buku kepustakaan, penerapan kaidah-kaidah atau norma-norma dalam hukum positif dan dokumen lainnya seperti peraturan perundang-undangan yang berkaitan dengan judul penelitian ini. ${ }^{4}$ Dalam penelitian yang dimaksud oleh penulis adalah penelitian yang dilakukan terhadap norma hukum tertulis dalam hal ini adalah pengambilalihan hak atas jaminan (eksekusi) jaminan fidusia dan rahn tasjily persepektif hukum positif dan hukum Islam.

\section{PEMBAHASAN}

\section{A. Sejarah dan Dasar jaminan Fidusia}

Istilah fidusia berasal dari bahasa Belanda, yaitu fiducie, sedangkan dalam bahasa Inggris disebut fiduciary transfer of ownership, yang artinya kepercayaan, ${ }^{5}$ yakni penyerahan hak milik atas benda secara kepercayaan sebagai jaminan (agunan) bagi pelunasan piutang kreditor. Penyerahan hak milik atas benda ini dimaksudkan hanya sebagai agunan bagi pelunasan utang tertentu, di mana memberikan kedudukan yang diutamakan kepada penerima fidusia (kreditor) terhadap kreditor lainnya. ${ }^{6}$ Di dalam Pasal 1 ayat (1) Undang-Undang Nomor 42 Tahun 1999 tentang Jaminan Fidusia kita jumpai pengertian fidusia. Fidusia adalah: "Pengalihan hak kepemilikan suatu benda atas dasar kepercayaan dengan ketentuan bahwa benda yang hak kepemilikannya yang diadakan tersebut tetap dalam penguasaan pemilik benda itu." Dari perumusan di atas, dapat diketahui unsur-unsur fidusia itu, yaitu: (1) Pengalihan hak

4 Soerjono Soekanto, Pengantar Penelitian Hukum, UI Press, Jakarta, 1983, hal, 51.

5 Salim HS, Perkembangan Hukum Jaminan Di Indonesia, Rajawali Pers, Jakarta, 2014, hlm. 55.

${ }^{6}$ Rachmadi Usman, Hukum Jaminan Keperdataan, Sinar Grafika, Jakarta, 2008, hlm. 151. 
kepemilikan suatu benda; (2) Dilakukan atas dasar kepercayaan; (3) Kebendaannya tetap dalam penguasaan pemilik benda.

Dengan demikian, artinya bahwa dalam fidusia telah terjadi penyerahan dan pemindahan dalam kepemilikan atas suatu benda yang dilakukan atas dasar fiduciair dengan syarat bahwa benda yang hak kepemilikannya tersebut diserahkan dan dipindahkan kepada penerima fidusia tetap dalam penguasaan pemilik benda (pemberi fidusia). Dalam hal ini yang diserahkan dan dipindahkan itu dari pemiliknya kepada kreditor (penerima fidusia) adalah hak kepemilikan atas suatu benda yang dijadikan sebagai jaminan, sehingga hak kepemilikan secara yuridis atas benda yang dijaminkan beralih kepada kreditor (penerima fidusia). Sementara itu hak kepemilikan secara ekonomis atas benda yang dijaminkan tersebut tetap berada di tangan atau dalam penguasaan pemiliknya. ${ }^{7}$

\section{Objek dan Pendaftaran Jaminan Fidusia}

Berdasarkan Undang-Undang ini objek fidusia dibagi 2 macam, yaitu, pertama, benda bergerak baik yang berujud maupun tidak berujud, dan kedua, benda tidak bergerak, khususnya bangunan yang tidak dibebani hak tanggungan. Yang dimaksud dengan bangunan yang tidak dibebani hak tanggungan di sini dalam kaitannya dengan bangunan rumah susun, sebagaimana yang diatur dalam UndangUndang Nomor 16 Tahun 1985 tentang Rumah Susun. ${ }^{8}$

Kewajiban untuk mendaftarkan fidusia ke instansi yang berwenang bersumber dari Pasal 11 Undang-Undang Nomor 42 Tahun 1999. Pendaftaran fidusia dilakukan pada Kantor Pendaftaran Fidusia di tempat kedudukan pihak pemberi fidusia. Pendaftaran fidusia

\footnotetext{
7 Ibid, hlm. 152.

8 H.Salim, Op-cit, hlm. 64.
} 
dilakukan terhadap hal-hal sebagai berikut: ${ }^{9}$ (1) Benda objek jaminan fidusia yang berada di dalam negeri; (2) Benda objek jaminan fidusia yang berada di luar negeri; (3) Terdapat perubahan isi Sertifikat Jaminan Fidusia.

Kewajiban pendaftaran jaminan fidusia dikuatkan dengan adanya PMK RI Nomor 130/PMK.010/2012 tentang Pendaftaran Jaminan Fidusia bagi perusahaan pembiayaan yang melakukan pembiayaan konsumen untuk kendaraan bermotor dengan pembebanan jaminan fidusia. Lebih lanjut ditegaskan pula pada Undang-Undang Nomor 42 tahun 1999 tentang Jaminan Fidusia Pasal 11 Ayat (1) bahwa benda yang dibebani dengan jaminan fidusia wajib didaftarkan agar bersetifikat Jaminan Fidusia pada Kantor Pendaftaran Fidusia Wilayah Kementerian Hukum dan HAM.

Tempat pendaftaran fidusia adalah di Kantor Pendaftaran Fidusia yang berada di bawah naungan Departemen Kehakiman RI. Kantor inilah yang akan mengurus administrasi pendaftaran jaminan fidusia. Kantor Pendaftaran Fidusia akan mencatat jaminan fidusia dalam Buku Daftar Fidusia. Pencatatan tersebut ditanggali dengan tanggal yang sama dengan tanggal penerimaan permohonan pendaftaran. Ketika dilakukan pencatatan dalam Buku Daftar Fidusia, petugas pendaftaran hanya berwenang melakukan pengecekan data saja. Permohonan pendaftaran fidusia disampaikan kepada Kantor Pendaftaran Fidusia dengan melampirkan suatu naskah yang disebut dengan "Pernyataan Pendaftaran Fidusia". ${ }^{10}$

\section{Proses Eksekusi Jaminan Fidusia}

Eksekusi berasal dari bahasa Belanda disebut Executie atau Uitvoering, dalam kamus hukum diartikan sebagai Pelaksanaan

\footnotetext{
${ }_{9}^{9}$ Munir Fuady, Jaminan Fidusia, Op, cit, hlm. 30

${ }_{10} \mathrm{Ibid}, \mathrm{hlm} .31$.
} 
Putusan Pengadilan. Menurut Retnowulan Sutantio dan Iskandar Oeripkartawinata menyatakan, bahwa Eksekusi adalah Tindakan paksaan oleh Pengadilan terhadap pihak yang kalah dan tidak mau melaksanakan putusan dengan sukarela. Sedangkan Sudikno Mertokusumo, menyatakan pelaksanaan putusan/Eksekusi ialah realisasi dari kewajiban pihak yang bersangkutan untuk memenuhi prestasi yang tercantum dalam putusan tersebut. ${ }^{11}$

Ketentuan dalam Pasal 29 ayat (1) Undang-Undang fidusia telah mengatur pelaksanaan eksekusi atas benda yang menjadi objek jaminan fidusia. Apabila debitur atau pemberi fidusia cedera janji, eksekusi terhadap benda yang menjadi objek jaminan fidusia dapat dilakukan dengan cara:

a. Pelaksanaan titel eksekutorial sebagaimana dimaksud dalam pasal 15 ayat (2) oleh penerima fidusia.

b. Penjualan benda yang menjadi objek jaminan fidusia atas kekuasaan penerima fidusia sendiri melalui pelelangan umum serta mengambil pelunasan piutangnya dari hasil penjualan.

c. Penjualan di bawah tangan yang dilakukan berdasarkan kesepakatan pemberi dan penerima fidusia jika dengan cara demikian dapat diperoleh harga tertinggi yang menguntungkan para pihak.

Dengan demikian undang-undang fidusia telah mengatur cara atau menciptakan beberapa model eksekusi atas benda yang menjadi objek jaminan fidusia. Berdasarkan ketentuan dalam Pasal 29 ayat (1) undang-undang fidusia, dapat diketahui bahwa apabila debitur atau pemberi fidusia cedera janji, eksekusi terhadap benda yang menjadi objek jaminan fidusia dapat dilakukan dengan cara sebagai berikut:

11 Ibid. hlm.14. 
a. Eksekusi berdasarkan grosse Sertifikat Jaminan Fidusia atau titel eksekutorial (secara fiat eksekusi) yang terdapat dalam sertifikat jaminan fidusia, yang dilakukan oleh penerima fidusia

b. Eksekusi berdasarkan pelaksanaan parate eksekusi melalui pelelangan umum oleh penerima fidusia

c. Eksekusi secara penjualan di bawah tangan oleh kreditor pemberi fidusia sendiri.

\section{B. Tinjauan Hukum Islam Terhadap Pengambilalihan Hak Atas Jaminan (Eksekusi) Rahn Tasjily}

Rahn Tasjily adalah jaminan dalam bentuk barang atas utang tetapi barang jaminan tersebut (marhun) tetap berada dalam penguasaan (pemanfaatan) rahin dan bukti kepemilikan nya diserahkan kepada murtahin. ${ }^{12}$ Ketentuan Khusus mengenai rahn tasjily diantaranya sebagai berikut: 13

a. Bahwa pinjaman dengan menggadaikan barang sebagai jaminan utang dalam bentuk rahn tasjily dibolehkan dengan ketentuan terdiri atas:

1) Rahin menyerahkan bukti kepemilikan barang kepada murtahin.

2) Penyimpanan barang jaminan dalam bentuk bukti sah kepemilikan atau sertifikat tersebut tidak memindahkan kepemilikan barang ke Murtahin. Dan apabila terjadi wanprestasi atau tidak dapat melunasi utangnya, Marhun dapat dijual paksa/dieksekusi langsung baik melalui lelang atau dijual ke pihak lain sesuai prinsip syariah.

3) Rahin memberikan wewenang kepada Murtahin untuk mengeksekusi barang tersebut apabila terjadi wanprestasi atau tidak dapat melunasi utangnya.

4) Pemanfaatan barang marhun oleh rahin harus dalam batas kewajaran sesuai kesepakatan.

12 Fatwa Nomor 68/DSN-MUI/III/2008 Tentang Rahn Tasjily

13 Ibid. 
5) Murtahin dapat mengenakan biaya pemeliharaan dan penyimpanan barang marhun (berupa bukti sah kepemilikan atau sertifikat) yang ditanggung oleh rahin.

6) Besaran biaya pemeliharaan dan penyimpanan barang marhun tidak boleh dikaitkan dengan jumlah pinjaman yang diberikan.

7) Besaran biaya sebagaimana dimaksud huruf e tersebut didasarkan pada pengeluaran yang riil dan beban lainnya berdasarkan akad Ijarah.

8) Biaya asuransi pembiayaan rahn tasjily ditanggung oleh rahin.

b. Ketentuan-ketentuan umum fatwa No.25/DSN-MUI/III/2002 tentang rahn yang terkait dengan pelaksanaan akad rahn tasjily tetap berlaku.

c. Ketentuan penutup jika terjadi perselisihan (persengketaan) di antara para pihak, dan tidak tercapai kesepakatan di antara mereka maka penyelesaiannya dilakukan melalui Badan Arbitrase Syarieeah Nasional atau melalui Pengadilan Agama.

\section{Penyitaan Jaminan Fidusia Berdasarkan Prinsip-Prinsip Syariah}

Penyitaan dalam Islam telah ada sejak zaman Rasulullah Sallallahu 'alaihiwasallam, pada saat itu Rasulullah menyita harta Muadz, kemudian menjualnya dan digunakan untuk melunasi hutang Muadz, seperti dalam hadis berikut ini: ${ }^{14}$

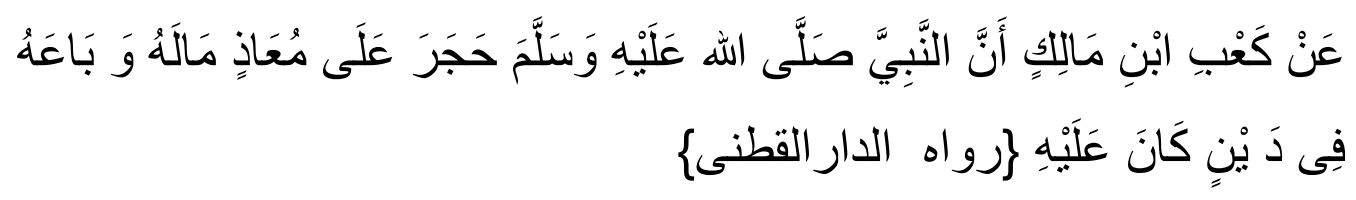

Artinya" : Sesungguhnya Nabi shallallahu 'alaihi wa sallam. pernah menyita harta Mu'adz dan menjualnya untuk membayar hutansgnya". (HR. ad-Daar alQuthni).

Dengan adanya hadis di atas dapat diketahui bahwa penyitaan dalam Islam itu diperbolehkan, karena Rasulullah Sallallahu'alaihi

14 Muhammad bin Ali bin Muhammad Asy-Syaukani, Nailul Authar Juz V, Mesir: Syirkah Maktabah wa Matba'ah Muthafa al-Halaby wa Auladuhu, t.th., hal. 275. 
Wasallam, sendiri pernah melakukannya, namun penyitaan seperti apa yang diperbolehkan dalam Islam, pastilah penyitaan yang tidak bertentangan dengan aturan-aturan dalam syariah atau hukum Islam.

Di dalam hukum Islam, apabila seseorang akan mengadakan jualbeli, sewa- menyewa dan hutang-piutang atau transaksi bisnis lainnya yang tidak secara tunai, maka hendaklah ditulis. Sebagimana firman Allah subhanahu wa ta'ala dalam QS. Al-Baqarah ayat 282 :
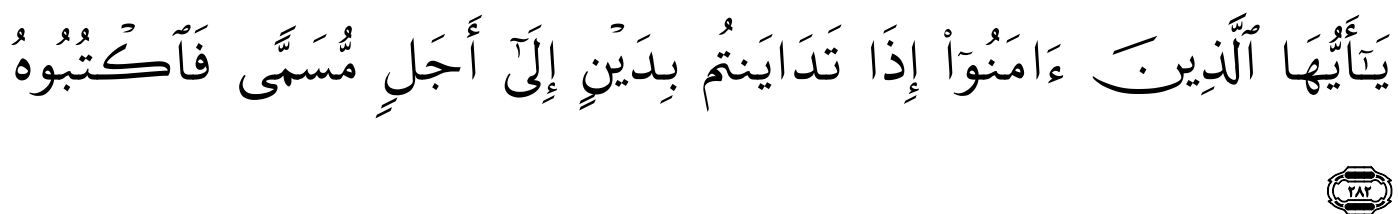

Artinya : "Hai orang-orang yang berimana apabila kamu bermuamalah tidak secara tunai untuk waktu yang di tentukan maka hendaklah kamu menuliskanya..."

Telah jelas kiranya bila dalam bertransaksi sesuai dengan prinsip Islam, maka menuliskan transaksi yang dilakukan adalah sebagai pijakan hukum yang digunakan apabila di kemudian hari terjadi hal-hal yang tidak diinginkan, seperti kejadian wanprestasi oleh salah satu pihak. Selain itu apabila dalam mengadakan akad jual beli atau hutang-piutang sedangkan sudah ditentukan akad pembayaranya maka hendaklah punya jaminan sebagai kekuatan hukum untuk menjamin hutangnya. Dalam hukum Islam juga dijelaskan melalui makna tersirat dari ayat ini, bahwa apabila terjadi perjanjian hutang-piutang dalam jangka waktu tertentu maka wajiblah janji itu dipenuhi dan pihak yang berhutang perlu membayar hutang itu menurut perjanjian.

Dalam penyitaan jaminan pada Rahn Tasjily pun juga demikian, penyitaan yang dilakukan harus dengan prosedur syariah. Dalam Kompilasi Hukum Ekonomi Islam (KHES) dijelaskan pada Pasal 364 ayat (1) tentang penjualan harta rahn disebutkan bahwa murtahin harus memperingatkan Rahin untuk segera melunasi hutangnya apabila telah 
jatuh tempo. Apabila belum ada peringatan dari murtahin untuk melunasi hutang dari rahin, maka penyitaan belum bisa dilakukan.

Setelah prosedur di atas dipenuhi dan telah sampai pada waktu yang ditetapkan maka pihak berhutang wajib untuk menyelesaikan hutangnya, jika ia mengalami kesulitan dalam melunasi hutangnya hendaklah diberi kelonggaran dan hal ini dijelaskan dalam QS. Al-Baqarah ayat $280: 15$

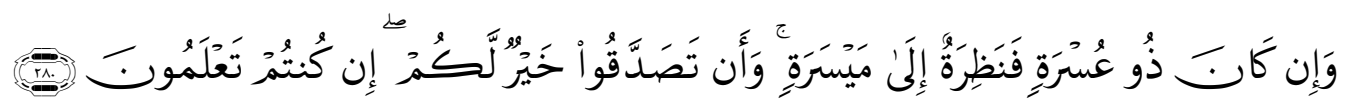

Artinya : "Dan jika ( orang berhutang) itu dalam kesukaran, maka berilah tangguh sampai ia kelapangan dan menyedekahkan sebahagian atau semuanya hutang itu lebih baik bagimu jika kamu mengetahui".

Sebelum penyitaan dilakukan hendaknya diberikan kelonggaran atau kesempatan untuk melunasi kredit yang masih macet, dalam Islam penyitaan tidak boleh serta-merta dilakukan tanpa melalui proses pemberian jangka waktu tertentu untuk mengatasi kredit macet yang terjadi. Setelah pemberian kelonggaran atau jangka waktu untuk pelunasan tersebut telah dilakukan, sedangkan pihak debitor tetap tidak dapat melunasinya, maka murtahin dapat meminta ganti rugi kepada rahin.

Dalam Konsep Ekonomi Islam menjadi sebuah anjuran kepada murtahin untuk memberikan penangguhan hutang terhadap rahin yang tidak mampu melunasi hutangnya, bahkan bagi murtahin yang mengikhlaskan untuk membebaskan hutang dijanjikan oleh Allah SWT pahala untuknya. Sebagaimana terdapat dalam ayat al-Quran surat alBaqarah $^{16}$ di bawah ini :

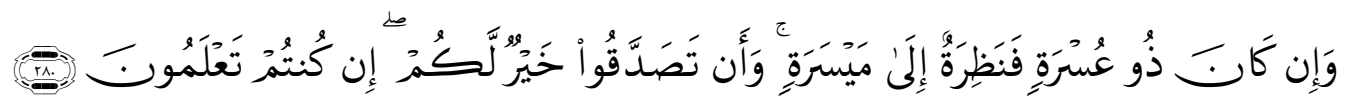

15 Al-Quran dan Terjemahnya Wakaf Dari Pelayan Dua Tanah Suci, hal. 70.

16 Ibid, hal. 70. 
Artinya : "Dan jika ( orang berhutang) itu dalam kesukaran, maka berilah tangguh sampai ia kelapangan dan menyedekahkan sebahagian atau semuanya hutang itu lebih baik bagimu jika kamu mengetahui".

Apabila ada seseorang yang berada dalam situasi sulit, atau akan terjerumus dalam kesulitan bila membayar hutangnya, maka tangguhkan penagihan sampai dia lapang. Jangan menagihnya jika kamu mengetahui dia sempit, apalagi memaksanya membayar dengan sesuatu yang amat dia butuhkan. ${ }^{17}$

\section{SIMPULAN}

Pengambilalihan hak atas jaminan (eksekusi) fidusia yang merupakan proses pengambilalihan hak atas jaminan (eksekusi) fidusia telah diatur dalam pasal 29 (1) Undang-Undang Jaminan Fidusia diantaranya, Eksekusi berdasarkan grosse (titel eksekutorial) secara fiat eksekusi, parate eksekusi, eksekusi secara penjualan di bawah tangan dan eksekusi fidusia secara mendaku. Pengambilalihan hak atas jaminan (eksekusi), Rahn Tasjily dasar hukumnya adalah fatwa Nomor: 25/DSN-MUI/III/2002, dan fatwa Nomor: 92/DSN-MUI/IV/2014. Namun faktanya yang terjadi bahwa pelaksanaan eksekusi yang dilakukan oleh lembaga pembiayaan belum mematuhi aturan perundang-undangan yang berlaku baik hukum positif dan hukum Islam.

\section{DAFTAR PUSTAKA}

Al-Quran dan terjemahanya waqaf dari Pelayan Dua Tanah Suci Raja Abdullah bin Abdul Aziz Ali sa'ud surat Al-Baqarah.

J. Satrio, 2007, Hukum Jaminan Hak Jaminan Kebendaan, Bandung : PT Citra Aditya Bhakti.

17 M. Quraish Shihab, Tafsir Al-Misbah, Jilid 1, Jakarta, Lentera Hati, 2002, hal. 569 
Muhammad bin Ali, bin Muhammad Asy-Syaukani, Nailul Authar Juz V, Mesir: Syirkah Maktabah wa Matba'ah Muthafa al-Halaby wa Auladuhu, t.th

Munir Fuady, 2003, Jaminan Fidusia, Cetakan. Ke-2, Citra Aditya Bakti, Bandung.,

M. Quraish, Shihab, 2002, Tafsir Al-Misbah, Jilid 1, Jakarta, Lentera Hati.

Rachmadi, Usman, 2008, Hukum Jaminan Keperdataan, Sinar Grafika, Jakarta.

Salim HS, 2014, Perkembangan Hukum Jaminan Di Indonesia, Rajawali Pers, Jakarta.

Satrio, 2007, Hukum Jaminan Hak Jaminan Kebendaan, Bandung : PT Citra Aditya Bhakti.

Soerjono, Soekanto, 1983, Pengantar Penelitian Hukum, Jakarta, UI Press.

Sri Soedewi, Masjchoen Sofwan, 1980, Hak Jaminan Atas Tanah, Yogyakarta, Liberty.

Undang-Undang No 42 Tahun 1999 tentang Jaminan Fiducia

Fatwa DSN-MUI No.68/DSN-MUI/III/2008 Tentang Rahn Tasjily. 